\title{
ERRATUM
}

C. Tucker Barrie - Craig Taylor - Doreen E. Ames

\section{Geology and metal contents of the Ruttan volcanogenic massive sulfide deposit, northern Manitoba, Canada}

The online version of the original article can be found at: http://dx. doi.org/10.1007/s00126-004-0455-7.

C. T. Barrie $(\bowtie)$

C. T. Barrie and Associates, Inc., 29 Euclid Avenue, Ottawa, ON, K1S2W2, Canada

e-mail: barriect@sympatico.ca

C. Taylor

Trout Lake Mine, Hudson Bay Mining and Smelting,

Flin Flon, MB, Canada

D. E. Ames

Geological Survey of Canada, 601 Booth Street,

Ottawa, ON, K1A0E8, Canada

\section{Mineralium Deposita (2005) 39:795-812}

Unfortunately, the publisher printed the author name and title with errors. The correct name and title are given above. 